\title{
Attitudes of college freshmen
}

\section{toward bibliographic instruction}

\author{
By Gordon B. Leighton \\ Instructor of English \\ Bellevue Community College
}

and Marsha C. Markman

Assistant Professor, Department of English

California Lutheran University

\section{Students prefer instruction that focuses on their own projects and includes some personal contact with librarians.}

ollege students, who face writing and research activities across the curriculum, need to acquire attitudes that will promote heightened interest in and enthusiasm about these activities. It is clear that in order to succeed in their college, professional, and even personal lives students need to develop their skills in writing and library research. Yet these frequently paired experiences, so necessary for student success, are commonly fraught with anxiety, which inhibits and diminishes performance.

The dilemma this poses for students led us to conduct three studies at a mid-Atlantic university. Our objective was to determine the attitudes of students in freshman composition classes toward the kind of bibliographic instruction they were receiving.

The first two of these studies examined student attitudes toward two types of BI provided by reference librarians. ${ }^{1}$ The first, a lecture and discussion practicum, was a hands-on session that focused on both basic research methods and students' individual research assignments. The second study ex-

${ }^{1}$ Marsha C. Markman and Gordon B. Leighton, "Exploring Freshman Composition Student Attitudes About Library Instruction Sessions and Workbooks: Two Studies," Research Strategies 5 (Summer 1987): 126-34. plored attitudes toward a self-guided workbook which contained research exercises that focused on prescribed topics and were evaluated by the library staff after being completed by students working on their own. Of the 497 students who received the lecture-discussion form of $\mathrm{BI}, 84 \%$ reflected a positive learning experience; however, of the 470 students who received the workbook form of instruction, only $69 \%$ responded positively.

\section{A new method}

As a result of those data and an independent study conducted by the library - and in deference to considerations about labor and cost which discouraged the discussion-practicum-a new BI book was prepared by a member of the library staff who sought the recommendations of several composition instructors. Unlike the workbook, this new resource, a comprehensive manual, permitted the students to work with their own topics. In addition, it required instructors, rather than librarians, to guide the students through the text and to evaluate the worksheets.

It seemed fitting that, with the introduction of a third teaching method, a follow-up study of student attitudes should be conducted and the new findings compared with the previous results. It was 
hoped that the research would help library staff and composition faculty to design experiences that would elicit the most positive student attitudes and provide an opportunity for maximum success in the research-writing process.

\section{The new BI manual}

The new manual was 37 pages in length: 31 pages of instructional material followed by 6 pages of individualized bibliographic worksheets. The instructional material was divided into seven sections corresponding to different types of print media (books, newspapers, periodicals, etc.). The material provided basic research information especially tailored to the campus library; maps of specific research areas were included, as were call numbers of some works, and short excerpts from indexes and abstracts. Worksheets guided the students toward finding the material needed for their own research projects.

The new manual was designed as a handbook for the students to use not only in their composition courses, but also in their other academic research projects. It was made available to students by the library and by those composition instructors who chose to use it in their classes.

\section{The sample group}

The sample consisted of 265 students enrolled in the second semester of a required freshman composition course in which a research paper was assigned. This number represents only those students who responded to the survey and includes approximately one-half of the number of students who enrolled in that course during the 1987-1988 academic year and one-half of each of the samples in the 1985 and 1986 studies. The reason for the smaller response is unclear, although it is evident that many instructors chose not to use the manual (some assigned projects for which class texts served as research sources).

\section{The instrument}

The Student Attitude Questionnaire was distributed at the end of the semester to all sections of the composition courses in which research is part of the curriculum. It was designed to closely parallel the instruments used in our previous studies. The objective was to measure attitudes toward the new manual and toward its usefulness in each student's research project. A further objective was to compare student attitudes toward the three different (and frequently used) methods of bibliographic instruction, and to make recommendations to our department and to the library regarding their use. All responses were anonymous.

\section{Analysis of the results}

Seventy-two percent of the students felt that they had a positive experience, learning "some," "quite a lot," or "a great deal," and $27 \%$ felt that they had learned "a little" or "nothing" following their use of the manual. In our previous studies, $84 \%$ reported a positive response to the lecture and discussion section, and $69 \%$ reported a positive response to the workbook.

Prior to using the manual, $38 \%$ of the students found library research "frustrating" or "frightening." Following its use, only $1.4 \%$ of the students said they were "disappointed" or "frustrated." Conversely, $11 \%$ of the students found research "exciting" and "interesting" before using the manual, and after using it, $32 \%$ were either "enthusiastic" or "encouraged."

When asked whether the manual was useful for their own research, $52 \%$ of the students said it was and $41 \%$ said it was not. Despite the relative lack of unanimity on that point, $90 \%$ thought that the manual should be continued, and only $5 \%$ disagreed.

\section{Discussion}

In general, the responses indicate that students felt they had learned library research strategies following their use of the manual; they displayed few negative feelings about the text; and they felt that the manual was beneficial to their own research. These results reflect more positive attitudes than we saw in the workbook study, but they also show a large increase in the percentage of neutral responses (from 55\% for the workbook to $64 \%$ for the manual).

In order to account for the difference in perception of this manual from that of the workbook, it may be noted that whereas the workbook provided "exercises" on a predetermined topic, the manual provided fill-in sheets that assisted students in generating bibliographies for their own research. Perhaps this direct relationship to the students' own work accounts for the absence of such hostile responses as "busy work," "ridiculous," "waste of time," which we saw in our study of the workbook. We know from student comments on the lecturediscussion practicum that they appreciate direct applicability of the skills they learn.

On the other hand, the large number of neutral responses (36\% reported feeling "all right" after using the manual and $28 \%$ reported "no change" in their feelings) may be related to negligible use of the manual: 37 students ( $14 \%$ ) said they did not use the manual, and 49 students (18\%) indicated that they used it very reluctantly, making comments like "Did not use it unless pushed to," "Only as much as 
my teacher made me," "almost none," "barely," "hardly at all."

We should be cautious in endorsing without qualification the use of a BI method on the basis that $90 \%$ of the sample felt it should be continued, since $32 \%$ admitted to using it very little or not at all. Because a number of students commented that, while they themselves felt no need for the manual, it might be useful for others, the $90 \%$ figure should be viewed with skepticism. Indeed, it would be misleading to assume that, because $90 \%$ of the students favored continuing the manual, the same $90 \%$ found it personally useful — especially in light of the large number of neutral and indifferent responses.

\section{Recommendations}

While our previous two studies underscored the importance that students place on personal interaction and their dissatisfaction and impatience with what they perceive as rudimentary work, this study indicates that a carefully prepared text might be welcomed under certain conditions. Therefore, and in view of student responses to the three methods of bibliographic instruction, we offer the following recommendations for preparing bibliographic instructional materials for freshman students:

1. While basic research strategies are necessary, instructional materials, especially those that include exercises, should enable students to focus on their own research projects. Hostile responses to the workbook indicated an aversion to work that was unrelated to students' own projects.

2. Students' attitudes, age, and academic experiences should be carefully considered. Studies of student attitudes about writing and library research underscore the importance of a positive attitude in overcoming destructive anxieties. Even experienced professionals find library research and writing frustrating and, at times, frightening. We should expect that our students-especially college freshmen-will experience at least as much research-writing anxiety as we do.

3. Some degree of personal guidance should accompany written materials. It is the lecturediscussion session that elicits the most positive student perception of learning about the library. College freshmen seem to appreciate and expect teacher-student interaction, an academic tradition which is as compatible with bibliographic instruction as it is with composition and other educational pursuits. Here we should also affirm the desirability of having professional librarians, rather than other faculty members, act as bibliographic instructors, since the librarian is versed on the intricacies of research in multiple fields, which may be foreign to faculty trained in specific areas. Indeed, recent research suggests a growing awareness of, and interest in, bibliographic instruction among professional librarians, who traditionally have not been trained to teach. ${ }^{2}$ We must each realize the importance of our own areas of expertise: the library science professional is best able to present the most creative and efficient way to use the library's cross-curriculum resources, and the instructor is best able to help the students synthesize the materials they have found into a coherent and effective written communication.

4. It is imperative that librarians and instructors cooperate fully in the preparation of BI materials. That spirit of cooperation was evident throughout our studies: consultations between library and composition faculty during the library's preparation of materials, easy availability of library staff to students, and a commitment to effective BI and to helping students overcome writing and research anxieties.

\section{Conclusion}

Library research, and the writing it reflects, frequently produce anxiety among college students. Lessening (even removing) that anxiety could allow students to approach and complete research-writing projects with confidence, competence, and satisfaction. To help students achieve these goals is to consider the kinds of library instruction that they value and find useful. And since bibliographic instruction cuts across departmental lines, planning and implementing BI methods should include active cooperation between faculty and library staff. This partnership should be one that strives to meet the needs of that most important third partner-and the beneficiary of the whole BI endeavor - the student.

${ }^{2}$ See, for example, Charles D. Patterson, "Li brarians as Teachers: A Component of the Educational Process," Journal of Education for Library and Information Science 28 (1987): 3-9; Mary Ellen Larson and Ellen Meltzer, "Education for Bibliographic Instruction," Journal of Education for Library and Information Science 28 (1987): 9-17.

\section{LOEX conference scheduled}

The theme of the annual LOEX conference will be "Working with Faculty in the New Electronic Library." The conference will be held May 10-11 in Ypsilanti, Michigan. To have your name put on the mailing list for a registration brochure, write or call: LOEX Clearinghouse, Eastern Michigan University Library, Ypsilanti, MI 48197; (313) 487-0168. 